\title{
Impact of Effective Succession Planning Practices on Employee Retention: Exploring the Mediating Roles
}

\author{
SYED NAJAM UL HASSAN (Corresponding Author) \\ Research Scholar \\ Karachi University Business School \\ University Of Karachi, Karachi, Pakistan \\ E-mail: syednajam4016@gmail.com
}

\section{DR. DANISH AHMED SIDDIQUI}

Associate Professor

Karachi University Business School, University Of Karachi, Karachi, Pakistan

E-mail: daanish79@ hotmail.com

Received: Jan. 28, 2020 Accepted: Feb. 24, 2020 Online published: Mar. 17, 2020

doi:10.5296/ijhrs.v10i2.16339

URL: https://doi.org/10.5296/ijhrs.v10i2.16339

\begin{abstract}
Succession planning (SP) and employee retention (ER) are mutually reinforcing. Meaning ineffective succession planning leads to turnover, and that would, in turn, make the succession plan ineffective. Hence the big challenge is to find how SP affects ER. For this, we proposed a model explaining the mediation effect of various factors on SP-ER nexus. We hypothesize that proper Succession planning produces a positive effect on Performance Goal Orientation, Supervisor Support, Working Environment, Rewards, Work-life Policies, Career Development, and Job Security. And these factors, in turn, lead to employee retention. We further assumed that the ER would lead to Organizational Effectiveness. To establish its empirical validity, we conducted a survey using a close-ended questionnaire. Data was gathered from 300 respondents who are serving in the middle and lower level of management in the private organizations in Pakistan. Data analysis was done through the descriptive statistics, partial least square (PLS), and Structural Equation Modeling (SEM) with the help of SmartPLS3. The findings indicated that effective succession planning practices had a meaningful, favorable connection with employee retention and out of seven mediators, only three mediators i.e. job security, rewards, and supervisor support significantly mediated the
\end{abstract}


association between effective succession planning practices and employee retention. Succession planning also seems to significantly affect the working environment, work-life policies, and career development. Results also exhibited that there's an insignificant link between effective succession planning practices and organizational effectiveness and also there is no positive relationship between employee retention and organizational effectiveness.

Keywords: Effective Succession Planning Practices (ESPP), Employee Retention (ER), Organizational Effectiveness (OE), Performance Goal Orientation (PGO), Supervisor Support (SS), Working Environment (WE), Rewards (REWD), Work-Life Policies (WLP), Career Development (CD), Job Security (JS) and Private Sector

\section{Introduction}

\subsection{Background to the Study}

Private sector firms in Pakistan facing the challenge of employee retention because the population of Pakistan mostly consists of youngsters who are active and creative always ready to switch over whenever he/she dissatisfied with any reason in the job. Succession planning (SP) is such an assertive strategy that makes sure that turnover does not exert harmful effects on organizations. In words of (Rothwell, 2010), Succession planning refers to a careful and organized action by a firm to assure management persistence in important positions, keeping and developing genius and knowledgeable human resources for the future, \& motivate individual advancement. (Adebola, 2019) states that succession planning reduces the time duration and expenditure of externally personal enlisting and hiring. Succession planning enhances employee's commitment, motivation and reduces the consequence of layoff nevertheless much extensively it develops the various group of talented \& competent human assets inside the firm. (Luna, 2012) asserted that SP refers to larger duration of systematic procedure of defining objectives, requirements, \& roles inside the firm and developing employees for duties associated with work needed inside the firm. Succession planning is aspired to assist organizations in controlling and keeping their talented individuals (Bolander et al, 2017). The major objective of succession planning is to develop adequate and potential executives to fill staff vacancies which are created by forthcoming immediate leaves of employees. Eventually, it rapidly contributes to enhancing employee retention rate in an organizational context. As suggested by (Abbasi and Hollman, 2000) employee retention explore as a mastery of retaining employee pool or the process of diminishing employee turnover within an organization. If we take a glance at the history and particularly analyze the time of world war two (WWII), we have noticed that from that time the concept of succession planning first emerged. (Henderson, 2005) asserts that succession planning program ensures to keep the most accurate person in an accurate position at an accurate time.

Effective implementation of SP can begin to be a more valuable technique in carrying actual talented individuals forward. Unluckily, most of the firms do not pay attention to seriously a helpful tool. It is assessed that nearly $70 \%$ of all succession planning programs fail in the long run as a result of snags in implementation (Prabhakar and Gowthami, 2013). According to (Khumalo and Harris, 2018) 67\% of global organizations have no succession plan in place whereas $45 \%$ do not have any developmental plans for their employees. In the year of 2004, 
the Society for Human resource management (SHRM) carried out a survey and states that $60 \%$ of firms had no succession plan at all (Dennis, 2005). Another survey conducted in the U.S by the Private Companies Practice Section (PCPS), out of 400 organizations, $60 \%$ of companies had owners aged 63-65 years and only 25\% of companies had written succession plans (2004). SP is a valuable method of seeking and development of competent executive but as well as it moreover helps in retaining staff inside the firm.

Most of the organizations in these days encouraging employees for learning and development to enhance their human resource for the purpose of creating competitive advantage (Johnson et al, 2018). Succession planning is an advanced tool that can create future pioneers and urge individuals to take part in learning and advancement opportunities. (Rothwell, 2010) asserted that SP is pivotal to accomplish the key goals of a firm as it enables the firm to fulfill the necessities required in the future by embracing new learning methods \& encouraging the development of highly capable executives. According to (Groves, 2003) succession planning acts as a technique for the management of talented human capital, development of leadership and the retention and creation of talent so as to make it possible for the organizations to make full use of their potential. Succession planning enables the organization to save the expense of external hiring and encourage inside executives to ensure a management position in the future. Individuals are more enthusiastic about their career progression and quests of jobs. It is, therefore, necessary that organizations must develop strategies like succession planning to ensure that they are capable of attracting and retaining talent within the organization. Turnover of staff is very costly for the organization and also it adds negative consequences on the firm's competitive advantage and future success. Execution of succession planning is limited nowadays because of the more flexible and instantly changing business environment. Hence succession planning practices become outdated as soon as they are made.

Effective Succession planning practices help to assure that talented and competent staff is developed to take on each major position in case of retirements, death, serious illnesses, etc. The absence of adequate succession planning programs in an organization can result in collapse of business on leave of valuable players (Garg and Van Weele, 2012). Less employee turnover and increase employee retention benefits in driving production and buyer value (Schroeder, Goldstein, \& Rungtusanatham, 2013). (Stadler, 2011) states that employees who are devoted are more likely to succeed in their work, stay longer in work and are less likely to leave. According to the survey conducted by the Society for Human Resource Management (SHRM)/Globoforce employee recognition report (SIA, 2018), employee retention has been one of the top manpower management challenges spotlighted by $47 \%$ of the HR leaders. Current emerging trends in the corporate world emphasize the necessity to invest in the active development of organization leaders (Cheng, 2016). Nonetheless, even though most of the executives are increasingly familiar with the need to concentrate on succession planning whereas very less is actively developing key organizational employees as part of their business strategy (Odengo, 2016). Hence, we chose to study the effect of ESPP on ER. This research paper aims to give a solution to the problem that how effective succession planning programs may increase employee retention. 


\subsection{Statement of the Problem}

In Pakistan, the situation is more complicated. Most of the privately-owned companies do not actually understand what succession planning is all about. Solely the family-owned businesses have the concept of succession planning. Few of the private companies implemented a succession plan but they don't have any written record. Succession planning is a more important activity for any firm that has to be executed.

There are some factors that create instability in the employees such as sickness, retirements, or search for better employment (Mehrabani and Mohamad, 2011). According to (Garg and Van Weele, 2012) lack of proper succession planning in an organization can lead to causing a collapse of a company after the exit of prominent individuals. (Human Resource Development Council, HRDC, 2012) reports that most of the manufacturing companies have a deficit of competent staff as a consequence of retirements, deaths, and skills walkout and switching jobs. Exits of retiring staff and fellow employees leaving the organization will have substantial implications (Hall-Ellis, 2015). As specified by (Rothwell, 2010) succession planning practices (SPP) refers to top management decision and practices utilized to promote and develop the employees in an organization and to assure that key positions are retained inside the company. Succession planning is not about having individuals, but also about getting the right individuals in the accurate place at an accurate time (Armstrong, 2011). Succession planning entails the right leadership at all levels of the company.

In the world of competition, it is a quite difficult and challenging task for organizations to retain their existing employees. Employees in each company are regarded as an important source of competitive advantage. Staff is considered as primary assets of the organization and their performance is crucial in organizational performance.

The concept of succession planning has got outdated in today's increasingly dynamic organizations. Most of the organizations give a lot of priority to talent management and development process by ignoring the reality that talented and ambitious employees look do not like to stay for longer periods to maintain their management positions (Armstrong, 2012). Nowadays the majority of the organizations are not executing effective succession planning practices that are should have to develop the best potential employees in the position of management. The outcome of this making the employees struggle to fill the job position particularly at the management level and tend to lead unhappiness among the employees that will further influence their performance and unable to retain talented employees (Eshiteti et al, 2013).

\subsection{Gap Analysis}

There are significant numbers of studies conducted which focuses on succession planning. (Chepkwony, 2012) conducted the study to investigate the relationship between talent management, succession planning and organizational strategy among the commercial banks and found that there is a connection between talent management, succession planning, and organizational strategy. (Eshiteti et al, 2013) examined the impact of succession plans on employee retention among Kenya's sugar companies and found that succession planning 
programs have a good effect on staff retention (W.A.D.N Poornima et al, 2018) executed a study and found that effective succession planning practices have a positive impact on retention of workforce of companies in private sector of Sri Lanka.

(Pita \& M. Dhurup, 2019) conducted a study in a South African public service organization and found that succession planning existing practices has an influence on intentions to leave. It was found that if succession planning is executed properly, the turnover intentions of the employees may be reduced. (Kowing Owee Tan et al, 2019) carried out a study on succession management practices and retention of the employee in the Malaysian property industry and found that succession management practices (career development initiatives, mentoring, counseling and employment rotation) are positively associated with retention of an employee. (Tamunomiebi, Miebaka Dagogo, and Okwakpam, Joy Amina, 2019) conducted a study on effective succession planning: a roadmap to employee retention and asserted that to retain valuable competent talent within the organization, organizations need an effective succession planning program.

Locally various studies have conducted on succession planning. For instance, (Syeda S. Gulzar and Abida Durrani, 2014) conducted a study in the Rawalpindi Telecommunication sector and found that succession planning is related significantly to employee engagement. (Zulqurnain Ali et al, 2014) examined the effect of succession planning on the performance of employees among Pakistan's commercial banks and reported that the links between succession planning and employee performance are significant. Another study is conducted on succession planning as a combating strategy for turnover intentions which found that succession planning offers job security and develops a successful career attitude which as a result mitigates the intentions of turnover among workforce (zulqurnain Ali and Aqsa Mehreen, 2018). (Zulqurnanin et al, 2019) conducted a study among employees of commercial banks of Pakistan and found that succession planning is significantly correlated to employee performance and the interaction has also been established by both the mediator i.e. career development and performance appraisal. (Zulqurnain and Aqsa Mehreen, 2019) investigated the study and state that succession planning has, directly and indirectly, an effect on engagement and employee performance through the job demands-resources (JD-R) model.

As per our knowledge, locally there is no research is conducted to address the connection between effective succession planning practices and the retention of staff among private sector organizations in the Pakistani context. Further, no one has evaluated the mediation effect of performance goal orientation, supervisor support, working environment, rewards, work-life policies, career development and job security in the correlation between effective succession planning practices and employee retention. Therefore in order to fill this gap, the present study examined how effective succession planning practices directly and/or indirectly linked to employee retention. One of the purposes of this study is to evaluate the existing succession planning practices inside the private sector organizations in order to know that how the organization's current succession planning practices deter the workers to abandon their intentions for leaving the organization. The reason for conducting this research is that Pakistan's private sector is one of the major contributors to the country's GDP. 


\subsection{Research Objectives}

The major importance of the current study was to infer the consequences of effective succession planning practices on employee retention. This research takes into account not only the effect of effective succession planning practices on employee retention but also considered some other factors such as performance goal orientation, supervisor support, working environment, rewards, work-life policies, career development, and job security as a mediator that have a positive or negative impact on employee's retention. The question to be analyzed in this research study is whether or not effective succession planning practices along with some mediators have an impact on the employee's retention. Every research study is carried out either at the organizational, environmental or marketing level, but our study is administered at the corporate level with the staff of middle and lower level of management of different private sector organizations of Karachi Pakistan.

The primary objectives of this study are:

1. To examine the influence of effective succession planning practices on employee retention.

2. To determine the impact of effective succession planning practices on organizational effectiveness.

3. To investigate the effect of employee retention on organizational effectiveness.

4. To examine the mediation role of different factors in the association between effective succession planning practices and employee retention.

\subsection{Research Question}

The major research questions of the study are given below.

- What is the impact of effective succession planning practices on employee retention?

- What is the impact of effective succession planning practices on organizational effectiveness?

- What is the impact of employee retention on organizational effectiveness?

- How different factors play a mediation role in the relationship between effective succession planning practices and employee retention?

\subsection{Significance of the Study}

The role played by the private sector organizations is crucial for the growth of the Pakistani economy. This study evaluates the employees of private sector business organizations of Pakistan and provides insight that how effective succession planning practices impact employee retention. Findings of the research generate valuable information to other organizations especially private sector business organizations that how effective succession planning programs can be implemented to retain talented employees. Primarily study results make a contribution to the enhancement of talented human capital base within an 
organization. According to this study, the executive will be able to keep productive human assets over an extended period without unexpected leaves and create a talented pool of human assets for future requirements. The data of this research study will assist the future scholars to administer a similar study and will also assist the companies to develop strategic guidance for developing effective succession planning program for the retention of their employees. Thus this research contributes to filling the knowledge gap.

\section{Literature Review}

\subsection{Effective Succession Planning Practices}

The organization's future plans may change for some purposes such as retirements, promotion, within the organization and severe sickness, casualty or any voluntary exit from the company to pursue employment elsewhere. To deal with such changes, companies should have a key employee replacement plan. For this concern, succession planning is deemed an adequate effort. As stated by (Eshiteti et al, 2013), it is strived to fill vacant positions at the management level as an outcome of serious dissatisfaction among employees. Best organizations incorporate effectively with both management advancement practices and SP practices. According to (Armstrong \& Taylor, 2014), management succession planning is a technique of developing competent executives to fill managerial vacancies within the organization. In the past, succession planning referred to a conventional process that contributes to developing a pool of competent leadership. As stated by (Groves, 2007) effective integration of the management development and succession planning process can optimize the utilization of managers and supportive organizational culture. Succession planning ensures the vitality and availability of leadership as well as encouraging employees through favorable organizational culture. Succession planning practices enable employees at all levels of management to build a positive organizational learning culture. (Mehrabani \& Mohamad, 2011) implies that how a company assesses and recognizes the importance of the personnel it has and what kind of human capital it will need in the future can decide the critical success for a company in the future. The (Human Capital Index Report, 2005) reveals that succession planning is one of the most important tools to decrease turnover costs. (Pennel, 2010) asserted that we need to analyze human efficacy and effectiveness in order to achieve organizational goals with respect to succession planning. Succession planning allows for a pool of talented people, which will help overcome the problem of inadequate individuals' selection. (Rothwell, 2001) stated that companies that have no systematic preparation of succession planning undergo distinct circumstances, i.e. they can not hire the correct individual at the correct place and at the correct time, fear of employee withdrawal, and key positions held by competitors.

\subsection{Employee Retention}

Employee retention is a very essential problem encountering organizational management due to the deficit of talented workers, economic development and loss of workers. Employee withdrawal is more expensive to an organization in monitory terms; it's consequences on worker motivation and buyer happiness (Eshiteti et al, 2013). (Tunje, 2014) asserted that employee retention is the ability of an organization to retain its employees from quitting the 
organization whereas lessening employee turnover. It is utilized to retain the most skilled and productive employees without withdrawal from the company. According to (Abbasi and Hollman, 2000) turnover concept described as the flow of workers among various companies as well as jobs. Retaining competent and talented human capital develops a similar value for staff and also for an organization. (Tews et al, 2014) stated that favorable inner work events negatively impacted employee turnover. Retention of staff and poor turnover leads to quality of output and buyer satisfaction (Schroeder, Goldstein and Rungtusanatham, 2013). According to (Chitsaz Isfahani and Boustani, 2014) asserted that staff retention is generally considered a capability to sustain a secure human resource. The number of researches has examined that controlling turnover is a challenging task for companies as distinct companies utilizing several strategies to keep the workforce (American Management Association, 2001).

\subsection{Link between Effective Succession Planning Practices and Employee Retention}

Succession planning is according to (Abbasi \& Hollman, 2000) is a retention program that enhances the organization's capability to keep its employees or discourages the employees to leave the organization. Effective succession planning practices provide organizations with a technique to solve matters like retiring employee and employee turnover intentions. Hence, organizations presently require attracting, developing and retaining competent employees who can become active leaders. Every firm makes an effort to keep those workers who have skills and potentials and have the needed skills that can add value to the firm. One key strategy is succession planning that many of the organizations need to focus on (Hiltrop JM, 1999). When succession planning is not carried out on time and properly as a result employees think of evacuating an organization. (Tunje, 2014) asserted that succession planning practices positively related to employee retention. (Nyamekye, 2012) conducted research on the topic of impact of motivation on retention of the employee at Standard Chartered Bank in Ghana and found that most of the employees had no intents to left the company as a result of successful long term career succession plans. According to (Nzuve, 2010) staff retention comprises all the organization's endeavors like succession planning need to assure the employees not to leave the organization. Succession planning improves the staff's career paths for the purpose of motivating staff and to lower the turnover rate.

H1: There is a positive relationship between effective succession planning practices and employee retention.

\subsection{Organizational Effectiveness}

The conclusive objective of succession planning is to enhance organizational efficiency and for that reason assure continuity and organizational effectiveness. As stated by (Charan, Drotter \& Noel, 2001) succession planning is beheld as a management pipeline that enables management and for that course organizational effectiveness over a period of time. (Beaver and Hot, 2004) claimed that succession planning is a component of human resource planning in accordance with the overall strategy of the company. According to (Vardiman, Houghston, and Jinkerson, 2006), companies with productive leaders incline to creative, respond to alterations in markets and environments, efficiently address challenges and maintain a high level of performance including enhanced financial performance leading to a high firm's 
effectiveness. (Avanesh, 2011) stated that succession planning through performance is positively related to organizational effectiveness. In today's era of business atmosphere, employee retention is a primary issue facing by the organizations. Without competent and well-integrated employees, companies can never experience long term success (Gentry et al, 2006). The effect of employee turnover leads to the additional workload for the existing employee's performance and on organizational effectiveness. Giving adequate attention to retention policies will enhance the organizational effectiveness in terms of greater productivity, quality and increase employee engagement and satisfaction.

H2: There is a significant relationship between effective succession planning practices and organizational effectiveness.

H3: Employee retention is positively related to organizational effectiveness.

\subsection{Performance Goal Orientation}

As stated by (Locke and Latham, 1990) goal theory was referred to as an individual nature toward developing or corroborating one's potential in accomplishment settings. The prominent goal was to utilize as the quick regulator of people's actions, guiding path and perseverance of job-related behavior. Performance goal acquainted employees mainly pursue to attain positive decisions or avoid adverse decisions through their existing task performance level (Colquitt \& Simmering, 1998). (Elliott \& Dweck, 1988) asserts that employees who have performance goal orientation view challenging situations as an opportunity to asses their skill rather than an opportunity to learn. Performance goal orientation cannot exert a positive impact on employee retention. As cited by (W.A.D.N Poornima et al, 2018) the majority of the Asian employees were aligned with the performance-avoidance. They were hoping to accept learning goal orientation instead of performance goal orientation. According to them, there is no moderator association between performance goal orientation moderator and employee retention. Employees who involved in performance goal orientation perceive a complex task as a danger because the risk of failure indicates their ineffective performance. On the other hand, employees who involved in learning goal orientations perceive a difficult task as an opportunity for advancement and growth (Vandewalle, Don, et al, 1999).

H4 (a): Effective succession planning practices is positively related to performance goal orientation.

H4 (b): Performance goal orientation is positively related to employee retention.

H4 (c): Performance goal orientation mediates the relationship between effective succession planning practices and employee retention.

\subsection{Supervisor Support}

One of the foremost critical elements that have an effect on the retention of the employee is the connection between an employee and a supervisor. According to (Rhoades and Eisenberger, 2002), supervisor support refers to the supervisor's actions in supporting their workforce to show skills, learning and attitudes obtain from the training program. The belief of an employee in a firm is greatly influenced by its connection to its supervisor (Eisenberger 
et al, 1990). (Greenhause, 1987) stated that employees who have support from a supervisor are less inclined to depart from the company and are much more involved by having a better association with the supervisor. As asserted by (Ontario, 2004), support from a supervisor is crucial to employee retention that employees leave managers rather than employment. Nowadays the workforce is so diverse which derives the value of worker supervisor relations for the retention of the workforce. (Borstorff and Marker, 2007) examined that workers expect trustworthy supervisors who value them, appreciate them and deal honestly with them. According to (Shoaib et al, 2009) abusive supervisors develop conflicts in employee's attitudes in terms of work, enterprise and life. Supervisor support is important for the good outcome of the organization and fair support from a supervisor makes employees feel satisfied, motivated and develop their skills through training programs and also decrease employee turnover. The success of the firm is based on staff retention and it is accomplished by delivering regular training and also encourages their workers for learning under the good support of the supervisor (Rizwan Qaisar Danish et al, 2019). Supervisor involvement and support must be strongly evident in the succession planning program. Supervisors should dedicated time and energy to the effective SP program. The Succession planning program is affected by the lack of support provided by the supervisor. (Rothwell, 2010) stated that one of the primary obstacles HR executives face in creating an organization succession plan is insufficient to support executives. Effective succession planning practices create a positive work relationship between supervisors and employees.

H5 (a): Effective succession planning practices positively related to supervisor support.

H5 (b): Supervisor support is positively related to employee retention.

H5 (c): Supervisor support mediates the relationship between effective succession planning practices and employee retention.

\subsection{Working Environment}

The working environment comprises physical factors around the work area of an employee and also all aspects that form part of the worker's involvement with the work itself. (Hytter, 2008) assessed that the working environment has usually been addressed by industrial viewpoint for example with a focus on physical facets such as massive loads, disturbances and access to the poisonous materials. Employees are happy to work in those companies which offer a favorable working environment where they know that they are creating a difference and where many of the employees inside the organization are competent and are working together to drive the business forward (Milory, 2004). Autonomous research executed by the American Society of Interior Designers (ASID) affirmed that the working environment plays a major role in the decision of the employee to stay or leave the employment (Madiha Shoaib et al, 2009). Save working environment encouraging employees to retain in the organization. The working environment seems to be a key influencer in the area of employee retention (Kossivi et al, 2016). Several investigators have been analyzed the positive effect of the working environment on the retention of an employee. (Nyanjom, 2013) refers to in his study that companies make efforts to altering undesirable working conditions that may drive workers to quit the company. Altering such a working environment enhances 
employees' happiness or increases the retention rate. A favorable working environment is believed to make employees experience good about coming to work and give the essential motivation to endure them throughout the day. A good succession planning program can help to make employees happy and satisfied which as a result will produce a more productive and successful working environment.

H6 (a): Effective succession planning practices positively impact on working environment.

H6 (b): Working environment is positively related to employee retention.

H6 (c): Working environment mediates the relationship between effective succession planning practices and employee retention.

\subsection{Rewards}

The reward is something that companies provide in response to the contribution of the workforce and also something that the workers desire (Agarwal, 1998). A reward consists of both extrinsic and intrinsic it can be in the form of money such as bonuses, or it can be in the form of recognition such as announcing an individual employee of the month. Rewards make employees motivated for future positive behavior. (Gilbert, 2005) stated that rewards have a sustainable effect on the workforce and it will proceed to vindicate workers thinking that they are appreciated. Rewards for employment satisfaction are extremely valuable because it meets both the fundamental demands and assists to achieve the higher-level objectives. Employee performance and their intention to stay on a job can influence by the rewards system of a firm (Bamberger and Meshoulam, 2000). Both the monetary and none monetary rewards are vital for increasing the retention of employees (Pillay, 2009). Succession planning rewards employees in the form of promotion to the future vacant position.

H7 (a): Effective succession planning practices is positively related to rewards.

H7 (b): Rewards is positively related to employee retention.

H7 (c): Rewards mediates the relationship between effective succession planning practices and employee retention.

\subsection{Work-Life Policies}

According to (Klopping, 2011), the balance of work is a control measure over how, where and when people work. The right balance between work and life is distinct for all because people have different preferences and different lives. (Rashid et al, 2013) executed a study aimed at assessing the connection between balancing of work-life and depression with the rate of turnover for workers. They observe that work-life balance has a significant relationship with the employee's turnover. (Ghayyur \& Jamal, 2012) also measured the significant connection between work-life balance and turnover intention of the worker. Aforementioned author postulate that workers who experience long working hours have to struggle for the needs of their family life and he believes that flexible working hours can have a positive effect on their workers in order to remain employed, happy and dedicated. Organizations are admitting that employees with a well-balanced job and lives are actually 
produced to the organizations. Work quality affects by employee's quality of personal life. Work-life balance policies enable workers in managing their work and family in a better position.

H8 (a): Effective succession planning practices is positively related to work-life policies.

H8 (b): Work-life policies are positively related to employee retention.

H8 (c): Work-life policies mediate the relationship between effective succession planning practices and employee retention.

\subsection{Career Development}

Career development is a vital factor for achieving individual goals (Kraimer et al, 2011). According to (Van der Sluis and Poell, 2003) career development means that individuals are proud of their work, their supervisors are happy with their work and individuals feel relaxed with their employment. According to (Heijden, Schalk, and Veldhoven, 2008) career development targeted at promoting and improving a career path with diversified versatility. (Ahmad, Mohamed, \& Manaf, 2017) investigated the succession planning program in the Malaysian public sector firms and observe that succession planning plays an important role in the development of employee career and improved morale in the leadership of the organization that as a result enhanced employee and firm performance. In the words of (Rothwell, 2010) for employee retention, succession planning plays a role by providing opportunities for career development. (Kramer et al, 2011) asserted that career opportunities make stronger managerial support for the growth and success of the workforce. The development of a career is essential for the employee and the organization (Hall, 2002). Organizations require skilled employees to maintain a sustainable competitive edge and people need career opportunities to advance and improve their skills (Prince, 2005). (Rothwell, 2010) stated that succession planning is a crucial predictor of career achievement that reasonably improves the employee's job behavior towards learning, mentoring, advancement and decreases employee's wish to leave. Succession planning authorizes the employees to concentrate effectively and efficiently on their career paths through opportunities to learn. (Heiden, 2007). According to (Farashah et al, 2011) succession planning makes employees focus on their career and update their career goals in accordance with corporate reform for accomplishing personal and also business goals. As asserted by (Heathfield, 2010) for successful succession planning program, someone should specify the organization's long term goal and also understand the development needs of your workers and as well as assuring that all key employees know their career paths and the roles for they are being developed to fill. In other words, succession planning is associated positively with career development.

H9 (a): Effective succession planning practices is positively related to career development.

H9 (b): Career development is related positively to employee retention.

H9 (c): Career development mediates the relationship between effective succession planning practices and employee retention. 


\subsection{Job Security}

Nowadays job security has served the most important element that impacts the employees to remain in a job. (Borland, 1992) described job security as freedom from fear of losing or removing from a job. According to (Greenhalgh and Rosenblatt, 2010) lack of job security leads to ambiguity in the future roles that leads to stress, disappointment, mental upheaval, exhaustion, and harm job security and improves retention. Job insecurity significantly increases employee turnover and has a detrimental effect on the health of employees. (Cheng \& Chan, 2008). (Staufenniel and Konig, 2010) proposed a job insecurity model, while analyzing the connection between absenteeism, turnover intentions and employee performance. They found that the effects of job insecurity are more complicated and more impediments are created for stressors. As suggested by (Lucky et al, 2013) job security intensifies the organizational performance. They observe that if an employee feels a high level of job security, then he carried out his work tasks more effectively. For this purpose, businesses are associating job security with opportunities for workforce development that include succession planning to maintain skilled and competent workers inside the organization. (Greenhalgh \& Rosenblatt, 1984) found that government jobs are viewed as more secure than private-sector jobs which are thought to provide less protection.

H 10(a): Effective succession planning practices is positively related to job security.

H 10(b): Job security is related positively to employee retention.

H 10(c) Job security mediates the relationship between effective succession planning practices and employee retention.

\section{Theoretical Framework}

An effective succession planning program is meant to lead to an efficient organization and has the power to influence employee retention at the work. In some instances, however, the strength of such relationships depends upon different factors that include seven mediators that are part of the main target of the study. The figure below shows a theoretical model of the study.

The present research is carried out to examine the effect of the independent variable (effective succession planning practices) on dependent variables (employee retention and organizational effectiveness) while carrying out performance goal orientation, supervisor support, working environment, rewards, work-life policies, career development \&, job security as the mediators between effective succession planning practices and employee retention in this case. 


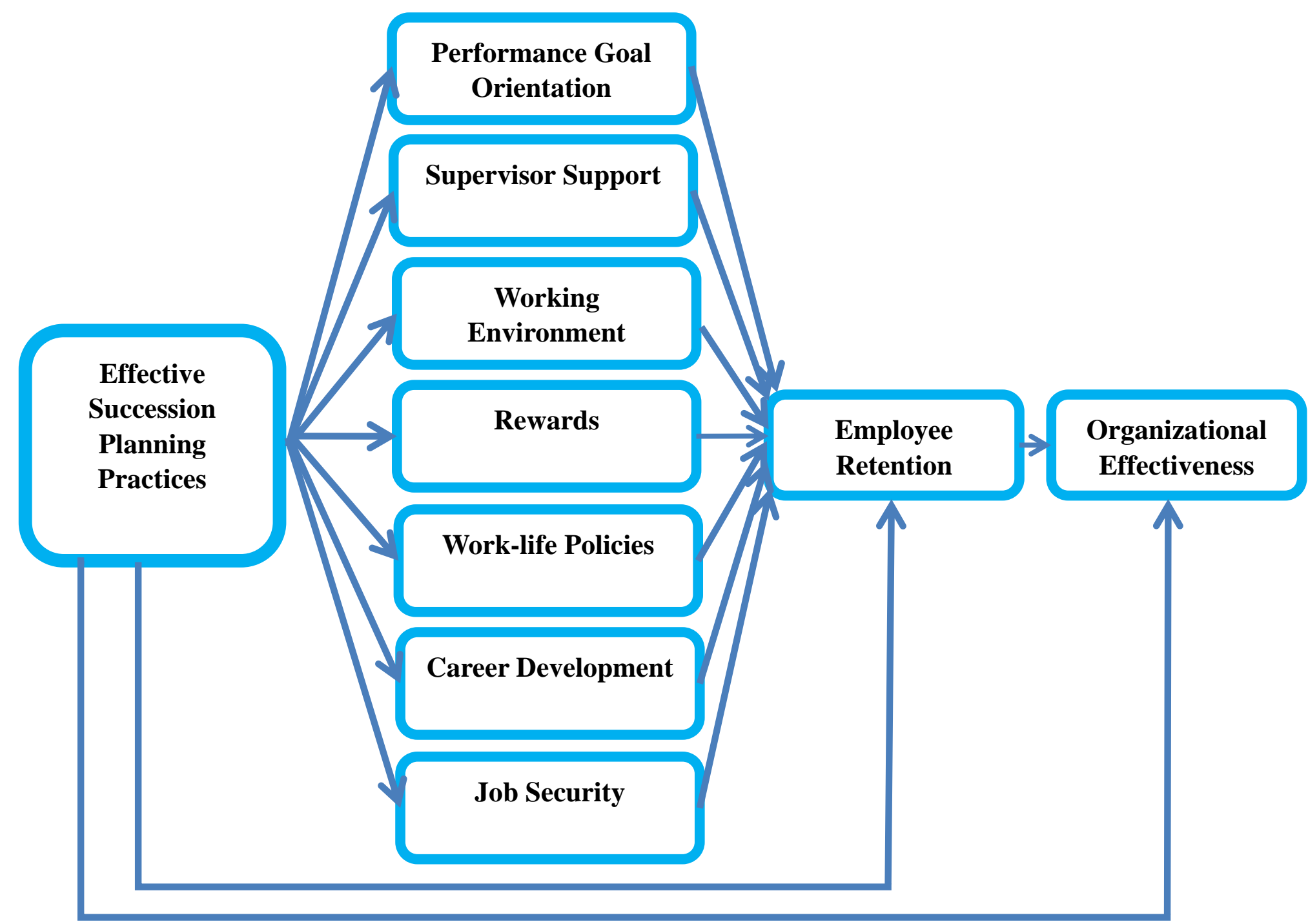

\section{Research Methodology}

\subsection{Nature of the Research}

The aim of this research was to evaluate the impact of ESPP on ER in private sector business organizations. This study adopts a descriptive survey design. The area of the research was based on private sector organizations in Karachi Pakistan. The researcher utilized a quantitative research technique for conducting the research study. The essential data was gotten with the help of questionnaires that were circulated among the middle and lower level managerial staff of various departments of the private organizations in Karachi.

\subsection{Population and Sample}

A sample of 300 respondents was included that comprises of both male and female employees of the various departments, i.e. Human resource, Finance, Marketing, Sales, Supply chain, Operations, and R\&D of different private organizations. 


\section{Macrothink}

International Journal of Human Resource Studies

ISSN 2162-3058

2020, Vol. 10, No. 2

\subsection{Questionnaire Development}

The questionnaire comprises of two sections the first section contains personal questions regarding sexual orientation, age, education, experience, \& income. These questions are hoped to get background information about the participants that would support in descriptive statistics in the analysis part. The second section contains questions regarding the research variables. The questions used to obtain responses on a five-point Likert scale. The points varied from "1" meaning "strongly disagree" to "5" meaning "strongly agree". All the questions in the questionnaire are close-ended.

The scale of effective succession planning practices, organizational effectiveness, and career development was taken from the working of Jonathan Tetteh (2015). The scale of employee retention was obtained from the research study of Jonathan Tetteh (2015) \& Tunje Grace Salama (2014). Performance goal orientation was adopted from the findings of Scott B. Button, et al (1996). Supervisor support was adopted from the research work of Gentry et al (2006). The Working environment was taken from the study of Janet Cheng Lian Chew (2004). Rewards were adopted from the research study of Silbert L.T (2005). Work-life policies were adopted from the findings of Guy Pare, et al (2001). And lastly, Job security was taken from the research work of Zeytinoglu et al (2010).

\subsection{Statistical Procedure}

Statistical techniques to analyze the data were Partial Least Square (PLS) and Structural Equation Modeling (SEM) by using SmartPLS3.

\section{Data Analysis and Results}

Table 1. Descriptive Statistics (Demographic Profile)

\begin{tabular}{|c|c|c|c|}
\hline \multirow{2}{*}{ Characteristics } & Measuring Group & Frequency & Percentage \\
\hline Gender & Male & 261 & 87 \\
\hline & Female & 39 & 13 \\
\hline Age & $22-30$ & 99 & 33 \\
\hline & $31-40$ & 107 & 35.6 \\
\hline & $41-50$ & 86 & 28.6 \\
\hline & $51-60$ & 8 & 2.6 \\
\hline Education & Above 60 & 0 & 0 \\
\hline & Graduation & 140 & 46.6 \\
\hline & Master & 136 & 45.3 \\
\hline & MPhil & 23 & 7.6 \\
\hline & PhD & 1 & .3 \\
\hline & $20,000-29,000$ & 72 & 39.6 \\
\hline & $30,000-39,000$ & 119 & 31.6 \\
\hline & $40,000-49,000$ & 95 & 3.6 \\
\hline
\end{tabular}




\begin{tabular}{|c|c|c|c|}
\hline & Above 60,000 & 3 & 1 \\
\hline Department & HR/Admin & 89 & 29.6 \\
\hline & Operation & 24 & 8 \\
\hline & Finance & 71 & 23.6 \\
\hline & Sales/Marketing & 98 & 32.6 \\
\hline Work Experience & R\&D & 18 & 6 \\
\hline & Less than 1 Year & 13 & 4.3 \\
\hline & $1-3$ Years & 62 & 20.6 \\
\hline & 4-6 Years & 144 & 48 \\
\hline & $7-9$ years & 72 & 24 \\
\hline Level of Management & Above 10-Years & 9 & 43.3 \\
\hline & Lower & 130 & 55 \\
\hline & Middle & 165 & 1.6 \\
\hline & Top & 5 & 100 \\
\hline
\end{tabular}

The table gave above illustrates the demographic profile of the respondents as there is a total of 300 respondents out of which $87 \%$ are Male \& $13 \%$ were Females. The age group of respondents are 22-30 years old (33\%), 31-40 years old (35.6\%), 41-50 years old $(28.6 \%)$, and 51-60 years old (2.6\%). The educations of respondents (46.6\%) are graduated, 45.3 are Masters Degree holder, and (7.6\%) are Mphil degree holder whereas (3\%) are PhD. The data on monthly income indicates that $(24 \%)$ of the respondent's monthly income is between $20,000-29,000,(39.6 \%)$ monthly income is between 30,000-39,000, (31.6\%) monthly income is between 40,000-49,000, (3.6\%) monthly income is between 50,000-59,000 and (1\%) monthly income is between above 60,000. (4.3\%) are less than 1 years of experience, (20.6) are 1-3 years of experience, (48\%) are 4-6 years of experience, $(24 \%)$ are 7-9 years of experience and (3\%) are above 10 years of experience. $(29.6 \%)$ of respondents are working in HR/Admin department, (8\%) are working in operation, (23.6) are working in Finance, $(32.6 \%)$ are working in Sales/Marketing and $(6 \%)$ of respondents are working in the R\&D department.

Table 2. Descriptive Statistics (Items Mean and Standard Deviation)

\begin{tabular}{|l|c|c|}
\hline Effective Succession Planning Practices & Mean & Standard Deviation \\
\hline $\begin{array}{l}\text { Succession planning practices exist and are actively used } \\
\text { in your organization. }\end{array}$ & 4.123 & 1.12 \\
\hline $\begin{array}{l}\text { In my organization succession planning puts into } \\
\text { consideration all key positions. }\end{array}$ & 4.057 & 1.083 \\
\hline In my organization succession plan formally documented. & 3.593 & 1.138 \\
\hline $\begin{array}{l}\text { In your organization succession plan encourages } \\
\text { promotion from within based on merit. }\end{array}$ & 3.957 & 1.15 \\
\hline $\begin{array}{l}\text { Job rotation is well implemented across all departments in } \\
\text { your organization. }\end{array}$ & 3.103 & 1.329 \\
\hline Succession planning improves employee's ability to & 4.287 & 0.985 \\
\hline
\end{tabular}




\begin{tabular}{|c|c|c|}
\hline \multicolumn{3}{|l|}{ respond to changing environmental demands. } \\
\hline Employee Retention & Mean & Standard Deviation \\
\hline $\begin{array}{l}\text { In your organization management is able to retain majority } \\
\text { of employees by practicing succession planning. }\end{array}$ & 4.043 & 1.053 \\
\hline $\begin{array}{l}\text { If it were up to me, I will definitely be working for this } \\
\text { company for the next five years. }\end{array}$ & 3.977 & 0.991 \\
\hline $\begin{array}{l}\text { A sense of being in management encourages you to stay in } \\
\text { the organization. }\end{array}$ & 4.017 & 0.874 \\
\hline $\begin{array}{l}\text { The existing succession plan in your organization } \\
\text { motivates employees to consider working until retirement } \\
\text { age. }\end{array}$ & 3.93 & 1.148 \\
\hline I see a future for myself within this company. & 3.95 & 0.98 \\
\hline Within this company my work gives me satisfaction. & 4.453 & 0.749 \\
\hline Organizational Effectiveness & Mean & Standard Deviation \\
\hline $\begin{array}{l}\text { There are no processes or organizational barriers to me } \\
\text { doing a good job. }\end{array}$ & 4.213 & 0.91 \\
\hline $\begin{array}{l}\text { The work that I do makes a difference to this } \\
\text { Organization. }\end{array}$ & 4.223 & 0.86 \\
\hline $\begin{array}{l}\text { I would recommend our organization to friends as a good } \\
\text { place to work. }\end{array}$ & 4.19 & 0.977 \\
\hline $\begin{array}{l}\text { I am trusted to make meaningful decisions in my day to } \\
\text { day activities. }\end{array}$ & 4.367 & 0.77 \\
\hline Performance Goal Orientation & Mean & Standard Deviation \\
\hline $\begin{array}{l}\text { I prefer to do things that I can do well rather than things } \\
\text { that I do poorly. }\end{array}$ & 4.167 & 0.952 \\
\hline $\begin{array}{l}\text { I'm happiest at work when I perform tasks on which I } \\
\text { know that I won't make any errors. }\end{array}$ & 4.12 & 1.101 \\
\hline The things I enjoy the most are the things I do the best. & 4.167 & 0.993 \\
\hline $\begin{array}{l}\text { I feel smart when I do something without making any } \\
\text { mistakes. }\end{array}$ & 4.277 & 0.833 \\
\hline Supervisor Support & Mean & Standard Deviation \\
\hline $\begin{array}{l}\text { In my organization, supervisor supports employees who } \\
\text { wish to advance in their careers through the Education } \\
\text { Policy and sponsorship for training. }\end{array}$ & 3.607 & 1.042 \\
\hline $\begin{array}{l}\text { In my organization, mentoring and coaching is well } \\
\text { practiced by supervisors. }\end{array}$ & 4.137 & 0.992 \\
\hline $\begin{array}{l}\text { In my organization, supervisor always support employees } \\
\text { and are willing to assist them anytime they seek guidance. }\end{array}$ & 4.36 & 0.982 \\
\hline My supervisor appreciates my work. & 4.273 & 0.787 \\
\hline Working Environment & Mean & Standard Deviation \\
\hline $\begin{array}{l}\text { My organization provides suitable and comfortable } \\
\text { working conditions (working space, sitting arrangemen }\end{array}$ & 4.247 & 0.901 \\
\hline
\end{tabular}




\begin{tabular}{|c|c|c|}
\hline ventilation and air conditions). & & \\
\hline $\begin{array}{l}\text { A spirit of cooperation and teamwork exists in my } \\
\text { organization. }\end{array}$ & 4.253 & 0.918 \\
\hline My working life balances with my family life. & 4.147 & 1.067 \\
\hline Overall this organization is harmonious place to work. & 4.16 & 0.942 \\
\hline Rewards & Mean & Standard Deviation \\
\hline $\begin{array}{l}\text { In my organization, rewards are given to all employees } \\
\text { without any form of discrimination. }\end{array}$ & 4.003 & 0.975 \\
\hline $\begin{array}{l}\text { In my organization, rewards are always given to talented } \\
\text { employees. }\end{array}$ & 3.717 & 1.182 \\
\hline The reward contributes greatly for my retention. & 4.073 & 1.024 \\
\hline $\begin{array}{l}\text { The reward program that my organization uses shows that } \\
\text { the organization makes special effort to recognize } \\
\text { employees. }\end{array}$ & 3.52 & 1.255 \\
\hline Work-Life Policies & Mean & Standard Deviation \\
\hline I often feel like there is too much work to do. & 3.36 & 1.555 \\
\hline $\begin{array}{l}\text { My work schedule in often in conflict with my personal } \\
\text { life. }\end{array}$ & 2.367 & 1.275 \\
\hline My job affects my role as a spouse and/or a parent. & 2.52 & 1.365 \\
\hline My job has negative effects on my personal life. & 2.247 & 1.326 \\
\hline Career Development & Mean & Standard Deviation \\
\hline $\begin{array}{l}\text { There are formal training programs in my organization to } \\
\text { teach employees the skills they need to perform their jobs. }\end{array}$ & 4.383 & 0.929 \\
\hline $\begin{array}{l}\text { I believe my promotion is a result of induction of the } \\
\text { training program. }\end{array}$ & 4.047 & 1.119 \\
\hline $\begin{array}{l}\text { I believe that my set targets and objective are attained and } \\
\text { identified by the firm through training Programs. }\end{array}$ & 3.263 & 1.278 \\
\hline $\begin{array}{l}\text { My career path is more in shape due to my participation in } \\
\text { training Program. }\end{array}$ & 4.147 & 1.054 \\
\hline Job Security & Mean & Standard Deviation \\
\hline $\begin{array}{l}\text { I feel secured in my job due to the implementation of } \\
\text { effective succession planning practices. }\end{array}$ & 4.15 & 1.146 \\
\hline I'm presently safe from dismissal at this organization. & 3.993 & 1.083 \\
\hline I feel I am likely to be laid off. & 2.067 & 1.121 \\
\hline $\begin{array}{l}\text { I am confident that this workplace will remain a steady } \\
\text { place of employment for as long as I want to continue } \\
\text { working here. }\end{array}$ & 4.197 & 1.073 \\
\hline
\end{tabular}

The table above illustrates the descriptive statistical analysis of the questions that were used to understand the impact of effective succession planning practices on retention of employees. The descriptive statistics are used for reporting, summing up and simplifying results. This makes it easier for us to communicate the data in a more meaningful way and will allow data to be understood more clearly. The above-given table displays the mean and standard 


\section{Macrothink

deviation of variables which are effective succession planning practices, employee retention, organizational effectiveness, performance goal orientation, supervisor support, working environment, rewards, work-life policies, career development, \& job security. Mean is the most widely used measure of the data center and also pertained as the numerical average. The standard deviation indicates the deviation in data. If the data are close together, then the standard deviation is small. The standard deviation will be big if the data is dispersed out. The given table illustrates the highest and lowest mean and standard deviation which is 4.453 at the highest mean value with 0.749 standard deviations and 2.52 at the lowest mean value with 1.365 standard deviations. The results indicate that the standard deviation is lower than the mean, since the mean could very well reflect the data.

\subsection{Inferential Statistics}

\subsubsection{Structural Equation Modeling (SEM)}

To examine the research hypothesis we have made use of the structural equation model (SEM) whereas the testing has been done with the help of software SmartPLS 3. Further to analyze the direct and indirect effects of all the constructs the testing was executed. It is carried out to analyze the structural relationship between exogenous and endogenous variables. Similarly, the notion of utilizing this model assures to employ technique of bootstrapping that has been deemed as acceptable for both small and big sample size and does not need any kind of indirect effect (Hayes, 2013). In order to test all the direct and indirect effects, a technique of bootstrapping has been carried out (Shrout \& Bolger, 2002).

\subsubsection{Measurement of Outer Model}

The purpose behind the measure of fit in the measurement model is to study the reliability and validity of the instrument \& to test its reliability and validity we conduct a test of convergent validity and discriminant validity through SmartPLS 3.

\subsubsection{Composite Reliability}

The reliability of the measurement instruments was analyzed by using composite reliability. All the values were greater than the commonly used threshold value i.e. 0.70 . This is the accepted reliability value range. Analysis of reliability can be carried out by the degree of constancy that lies amongst several variables (Hair 2010). 
Table 3. Composite Reliability

\begin{tabular}{|l|c|}
\hline \multicolumn{1}{|c|}{ Variables } & Composite Reliability (Cronbach Alpha's) \\
\hline Career Development & 0.755 \\
\hline Employee Retention & 0.802 \\
\hline Effective Succession Planning Practices & 0.853 \\
\hline Job Security & 0.782 \\
\hline Organizational Effectiveness & 0.838 \\
\hline Performance Goal Orientation & 0.748 \\
\hline Rewards & 0.756 \\
\hline Supervisor Support & 0.703 \\
\hline Working Environment & 0.754 \\
\hline Work-Life Policies & 0.770 \\
\hline
\end{tabular}

The normal threshold value of Cronbach Alpha's is 0.70 to 1. Data are meant to be reliable and strong if Cronbach Alpha's lies between the above-given range (Ekwoaba, Ikeiji, et al. 2015). The Cronbach Alpha's value of the independent variable effective succession planning practices has 0.853 with the number of 6 items. This is indicating a solid and reliable Cronbach Alpha's. The Cronbach Alpha value of the two dependent variables i.e. employee retention and organizational effectiveness has 0.802 with the number of 6 items and 0.838 with the number of 4 items. This also shows a reliable Cronbach Alpha's, whereas the value of the Cronbach Alpha for career development has 0.755 with the number of 4 items. The Cronbach Alpha value for job security has 0.782 with the number of 4 items. The Cronbach Alpha value for performance goal orientation has 0.748 with the number of 4 items. The Cronbach Alpha value for rewards has 0.756 with the number of 4 items. The Cronbach Alpha value for supervisor support has 0.703 with the number of 4 items. The value of Cronbach Alpha for the working environment has 0.754 with the number of 4 items. The Cronbach Alpha value for work-life policies has 0.770 with the number of 4 items. This is indicating that the Cronbach Alpha's value of all the mediators has greater than normal threshold value i.e. 0.70 so that all the coefficients are solid and reliable.

\subsubsection{Convergent Validity}

Convergent validity deals to the degree to which a measure relates favorably with an alternative measure of a similar variable (Hair et al, 2013). Convergent validity is the degree of agreement in at least two measures of the same construct (Carmines and Zeller 1979). Convergent validity was evaluated by examination of variance mined for each factor (Fornell and Larcker 1981). The average variance extracted (AVE) was computed to access convergent validity. 
Table 4. Convergent validity

\begin{tabular}{|l|c|c|c|c|}
\hline \multicolumn{1}{|c|}{ Variables } & $\begin{array}{c}\text { Cronbach's } \\
\text { Alpha }\end{array}$ & rho_A & $\begin{array}{c}\text { Composite } \\
\text { Reliability }\end{array}$ & $\begin{array}{c}\text { Average Variance } \\
\text { Extracted (AVE) }\end{array}$ \\
\hline Career Development & 0.755 & 0.767 & 0.759 & 0.515 \\
\hline Employee Retention & 0.802 & 0.816 & 0.805 & 0.512 \\
\hline Effective Succession Planning Practices & 0.853 & 0.855 & 0.854 & 0.661 \\
\hline Job Security & 0.782 & 0.786 & 0.784 & 0.645 \\
\hline Organizational Effectiveness & 0.838 & 0.876 & 0.768 & 0.504 \\
\hline Performance Goal Orientation & 0.748 & 0.905 & 0.907 & 0.851 \\
\hline Rewards & 0.756 & 0.757 & 0.755 & 0.508 \\
\hline Supervisor Support & 0.703 & 0.704 & 0.703 & 0.542 \\
\hline Working Environment & 0.754 & 0.781 & 0.755 & 0.514 \\
\hline Work-Life Policies & 0.770 & 0.773 & 0.771 & 0.529 \\
\hline
\end{tabular}

Table. 2 shows the values of Cronbach Alpha's, Rho, and Composite reliability of all latent variables are greater than the threshold value of 0.70 whereas average variance extracted (AVE) values are more than the normal threshold value 0.5 (Hair et al, 2006) for all the variables including effective succession planning practices, employee retention, organizational effectiveness and following mediators including performance goal orientation, supervisor support, working environment, rewards, work-life policies, career development, and job security. However convergent validity is established.

\subsubsection{Discriminant Validity}

This is the degree by which a variable is really different from other variables in terms of how greatly it correlates with other variables and how much indicators depict only a single variable (Hair et al, 2013). (Carmines \& Zeller, 1979) define discriminant validity as any individual construct when differentiating from other constructs inside the model. The criterion and cross-loading scores of (Fornell and Larcker, 1981) were employed to build discriminant validity. Discriminant findings are acceptable when the constructs are having average variance extracted (AVE) loading greater than 0.5 which implies that a minimum $50 \%$ of the variance was taken by the construct (Chin, 1998). Discriminant validity is created when the diagonal elements are significantly larger than off-diagonal values in parallel rows and columns. 
Table.5 Discriminant validity

\begin{tabular}{|l|c|c|c|c|c|c|c|c|c|c|}
\hline & CD & ER & ESPP & JS & OE & PGO & REWD & SS & WE & WLP \\
\hline Career Development (CD) & 0.717 & & & & & & & & & \\
\hline Employee Retention (ER) & 0.686 & 0.715 & & & & & & & & \\
\hline Effective Succession Planning Practices (ESPP) & 0.569 & 0.539 & 0.813 & & & & & & & \\
\hline Job Security (JS) & 0.674 & 0.522 & 0.781 & 0.803 & & & & & & \\
\hline Organizational Effectiveness (OE) & -0.021 & -0.053 & -0.117 & -0.093 & 0.710 & & & & & \\
\hline Performance Goal Orientation (PGO) & -0.027 & -0.040 & -0.102 & -0.094 & 0.513 & 0.922 & & & & \\
\hline Rewards (REWD) & 0.454 & 0.334 & 0.710 & 0.677 & 0.018 & 0.781 & 0.712 & & & \\
\hline Supervisor Support (SS) & 0.544 & 0.45 & 0.790 & 0.581 & 0.0520 .730 & 0.603 & 0.736 & & \\
\hline Working Environment(WE) & -0.041 & -0.074 & -0.153 & -0.121 & 0.918 & 0.688 & -0.018 & 0.058 & 0.717 & \\
\hline Work-Life Policies (WLP) & -0.765 & -0.633 & -0.625 & -0.717 & -0.027 & 0.005 & -0.663 & -0.637 & -0.032 & 0.727 \\
\hline
\end{tabular}

Table.3 illustrates that the square root of the average variance extracted (AVE) for all latent variables was greater than the inter-construct correlations (Fornell \& Larcker, 1981) and thus they confirm discriminant validity.

\subsubsection{Hypothesis Testing}

PLS-SEM bootstrapping is a key technique that gives the information of stability of coefficient measure. In this procedure, a big amount of sub-samples are drawn from the original sample with alternative (Hair et al, 2016). After running the bootstrapping, SmartPLS displays the $\mathrm{t}$-values for the structural model estimates that originated from the bootstrapping procedure. The results of the path coefficients and specific indirect effects for all the hypotheses are displayed in the table given below. If the t-value larger than 1.96 and $\mathrm{p}$-value less than 0.05 indicates that the relationship is significant at a 0.05 significance level. However, if the t-value less than 1.96 and a p-value greater than 0.05 , showed that relationship is insignificant. Path displaying whether the relationship between measured and latent variables are significant or not. The path diagram exhibited in figures $1 \& 2$.

Table 6. Hypothesis Testing

\begin{tabular}{|c|c|c|c|}
\hline Hypothesis & T-values & P-values & Decision \\
\hline $\begin{array}{l}\text { H1: There is a positive relationship between effective succession planning practices and } \\
\text { employee retention. }\end{array}$ & 7.254 & 0.000 & Accepted \\
\hline $\begin{array}{l}\text { H2: There is a significant relationship between effective succession planning practices and } \\
\text { organizational effectiveness. }\end{array}$ & 1.287 & 0.169 & Rejected \\
\hline H3: Employee retention is positively related to organizational effectiveness. & 0.725 & 0.461 & Rejected \\
\hline $\begin{array}{l}\text { H4 (a): Effective succession planning practices is positively related to performance goal } \\
\text { orientation. }\end{array}$ & 1.428 & 0.194 & Rejected \\
\hline H4 (b): Performance goal orientation is positively related to employee retention. & 0.439 & 0.652 & Rejected \\
\hline $\begin{array}{l}\text { H4 (c): Performance goal orientation mediates the relationship between effective succession } \\
\text { planning practices and employee retention. }\end{array}$ & 0.365 & 0.716 & Rejected \\
\hline H5 (a): Effective succession planning practices positively related to supervisor support. & 11.774 & 0.000 & Accepted \\
\hline
\end{tabular}




\begin{tabular}{|c|c|c|c|}
\hline H5 (b): Supervisor support is positively related to employee retention. & 2.968 & 0.003 & Accepted \\
\hline $\begin{array}{l}\text { H5 (c): Supervisor support mediates the relationship between effective succession planning } \\
\text { practices and employee retention. }\end{array}$ & 2.999 & 0.003 & Accepted \\
\hline H6 (b): Working environment is positively related to employee retention. & 0.096 & 0.924 & Rejected \\
\hline $\begin{array}{l}\text { H6 (c): Working environment mediates the relationship between effective succession planning } \\
\text { practices and employee retention. }\end{array}$ & 0.092 & 0.927 & Rejected \\
\hline H7 (a): Effective succession planning practices is positively related to rewards. & 11.181 & 0.000 & Accepted \\
\hline H7 (b): Rewards is positively related to employee retention. & 3.081 & 0.002 & Accepted \\
\hline $\begin{array}{l}\text { H7 (c): Rewards mediates the relationship between effective succession planning practices } \\
\text { and employee retention. }\end{array}$ & 2.863 & 0.004 & Accepted \\
\hline H9 (a): Effective succession planning practices is positively related to career development. & 20.003 & 0.000 & Accepted \\
\hline H9 (b): Career development is related positively to employee retention. & 0.998 & 0.319 & Rejected \\
\hline $\begin{array}{l}\text { H9 (c): Career development mediates the relationship between effective succession planning } \\
\text { practices and employee retention. }\end{array}$ & 0.994 & 0.321 & Rejected \\
\hline H10 (a): Effective succession planning practices is positively related to job security. & 18.643 & 0.000 & Accepted \\
\hline H10 (b): Job security is related positively to employee retention. & 2.840 & 0.003 & Accepted \\
\hline $\begin{array}{l}\text { H10 (c): Job security mediates the relationship between effective succession planning } \\
\text { practices and employee retention. }\end{array}$ & 2.905 & 0.004 & Accepted \\
\hline
\end{tabular}

A table given above shows the results of the hypothesis. The p-value of $\mathrm{H} 1$ is less than 0.05 which indicates that there is a positive impact of effective succession planning practices on employee retention. Therefore H1 was accepted. It is suggested when effective succession planning practices are increasing, there was a possibility for improving employee retention in the private sector organizations in Pakistan. Effective succession planning practices are more important for any organization in order to bring the competent individual forward to the key positions wherever all the decisions are to be taken which related to business. If effective succession planning practices carried out effectively as a result, it can enhance the employee rate of retention within the organization. The significant impact of effective succession planning practices on employee retention is also in accordance with the findings of some previous researchers (Eshiteti et al, 2013) and (Poornima W.A.D.N et al, 2018). The p-value of $\mathrm{H} 2$ is greater than 0.05 which shows that the relationship between effective succession planning practices and organizational effectiveness is insignificant which means that there is no impact of effective succession planning practices on organizational effectiveness. The H3 proposes that employee retention is not positively related to organizational effectiveness because the p-value is greater than 0.05 . Hence H3 was rejected. The p-value of H4(a) is larger than 0.05 which means that there is no impact of effective succession planning practices on performance goal orientation. Therefore H4(a) was rejected. The H4(b) predicts that performance goal orientation is not positively related to employee retention as the 
p-value of performance goal orientation is greater than 0.05 . Hence H4(b) was rejected. The p-value of H4(c) is greater than 0.05 which means that performance goal orientation does not mediate the relationship between effective succession planning practices and employee retention. Thus H4(c) was rejected. The H5(a) anticipates that effective succession planning practices are significantly correlated with supervisor support as the p-value is less than 0.05 . Therefore H5(a) was accepted. The p-value of H5(b) is less than 0.05 which indicates that there is a positive impact of supervisor support on employee retention which means that higher the support provided by the supervisors in the organizations, then higher will be the employee retention. Therefore H5(b) was accepted. The H5(c) proved that supervisor support successfully mediated the relationship between effective succession planning practices and employee retention as the p-value is less than 0.05. Hence H5(c) was accepted. The H6(a) indicates that effective succession planning practices are positively related to the working environment of an organization as the result shows that the p-value is smaller than 0.05. Therefore H6(a) was accepted. The H6(b) proposed that there is an insignificant impact of the working environment on employee retention as the findings show that the p-value is greater than 0.05. Hence we say that the working environment has no influence on employee retention. Thus H6(b) was rejected. The H6(c) anticipates that the indirect relationship between effective succession planning practices and employee retention through the working environment was not significant as the p-value greater than 0.05. Therefore H6(c) was rejected. The H7(a) shows that effective succession planning practices and rewards are positively correlated with each other as the p-value is less than 0.05 . Therefore H7(a) was accepted. The p-value of $\mathrm{H} 7(\mathrm{~b})$ is smaller than 0.05 which shows that there is a significant relationship between rewards and employee retention. it means that if an organization gives reasonable rewards to its employees on the basis of good performance, as a result, employees retain within the organization. Therefore H7(b) was accepted. The H7(c) proposes that the indirect relationship between effective succession planning practices and employee retention through the rewards was significant as the p-value less than 0.05. Hence H7(c) was accepted. The H8(a) predicts that effective succession planning practices positively correlated with work-life policies as the p-value is less than 0.05 . Therefore H8(a) was accepted. The p-value of H8(b) indicates that there is an insignificant impact of work-life policies on employee retention. The $\mathrm{H} 8(\mathrm{~b})$ is rejected as the p-value is greater than 0.05 . The H8(c) shows that a work-life policies is not mediated by the relationship between effective succession planning practices and employee retention. Therefore H8(c) was rejected as the p-value is larger than 0.05. The H9(a) predicts that effective succession planning practices are positively related to career development. Hence H9(a) was accepted as the p-value less than 0.05. The p-value $\mathrm{H} 9$ (b) is greater than 0.05 which implies that there is an insignificant relationship between career development and employee retention. Therefore H9(b) was rejected. The H9(c) indicates that the indirect relationship between effective succession planning practices and employee retention through career development was insignificant as the p-value is more than 0.05. Thus H9(c) was rejected. The H10(a) proposes that effective succession planning practices are positively related to job security as the p-value is less than 0.05 . Hence H10(a) was accepted. The H10(b) indicates that there is a significant relationship between job security and employee retention as the p-value is smaller than 0.05. Thus H10(b) was 


\section{Macrothink}

International Journal of Human Resource Studies

ISSN 2162-3058 2020, Vol. 10, No. 2

accepted. The H10(c) anticipates that the indirect relationship between effective succession planning practices and employee retention through job security was significant as the p-value is less than 0.05 . Therefore $\mathrm{H} 10$ (c) was accepted.

\subsubsection{PLS-Algorithm}

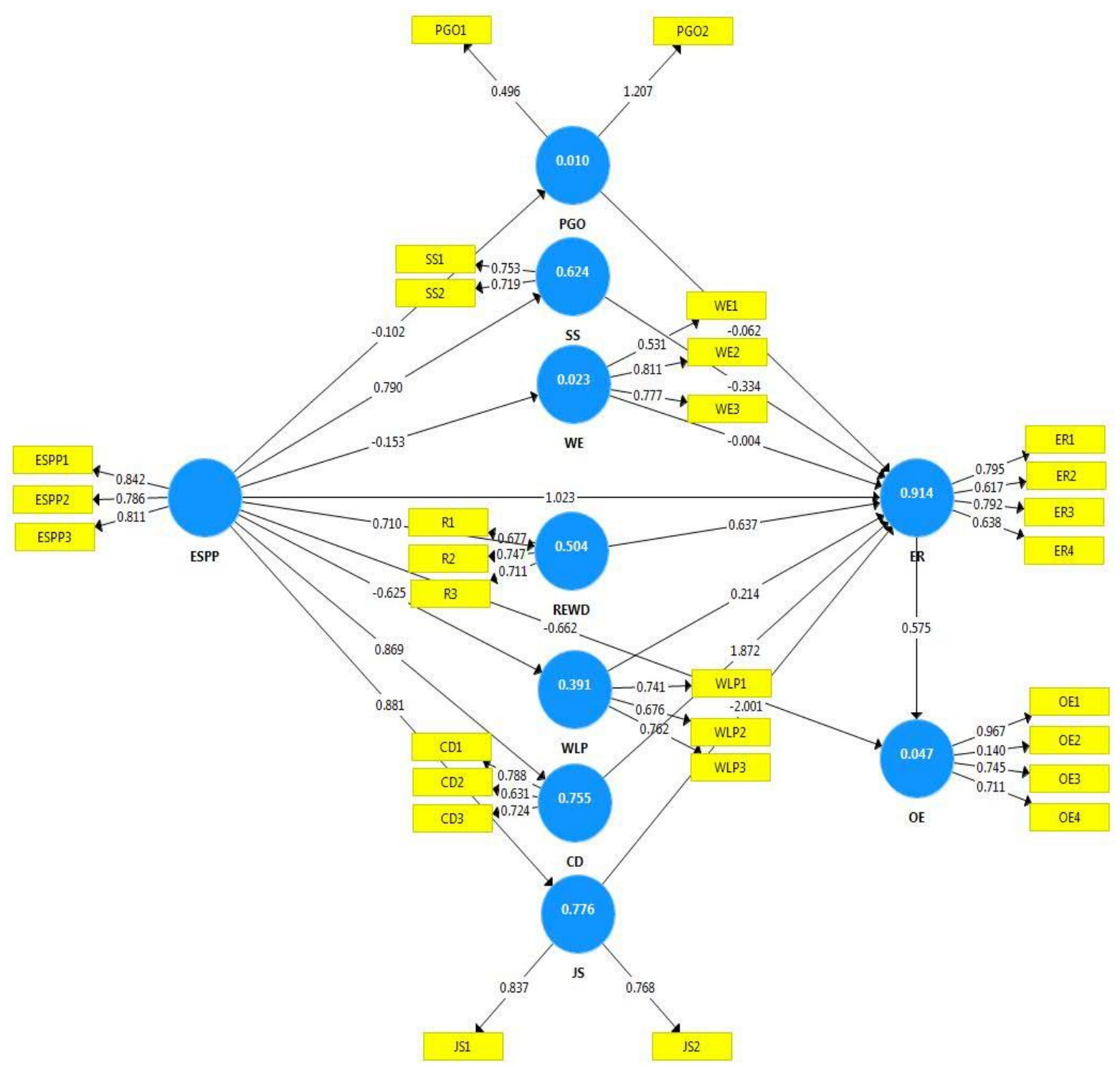

Figure 1. 
5.2.8 PLS-Bootstrapping

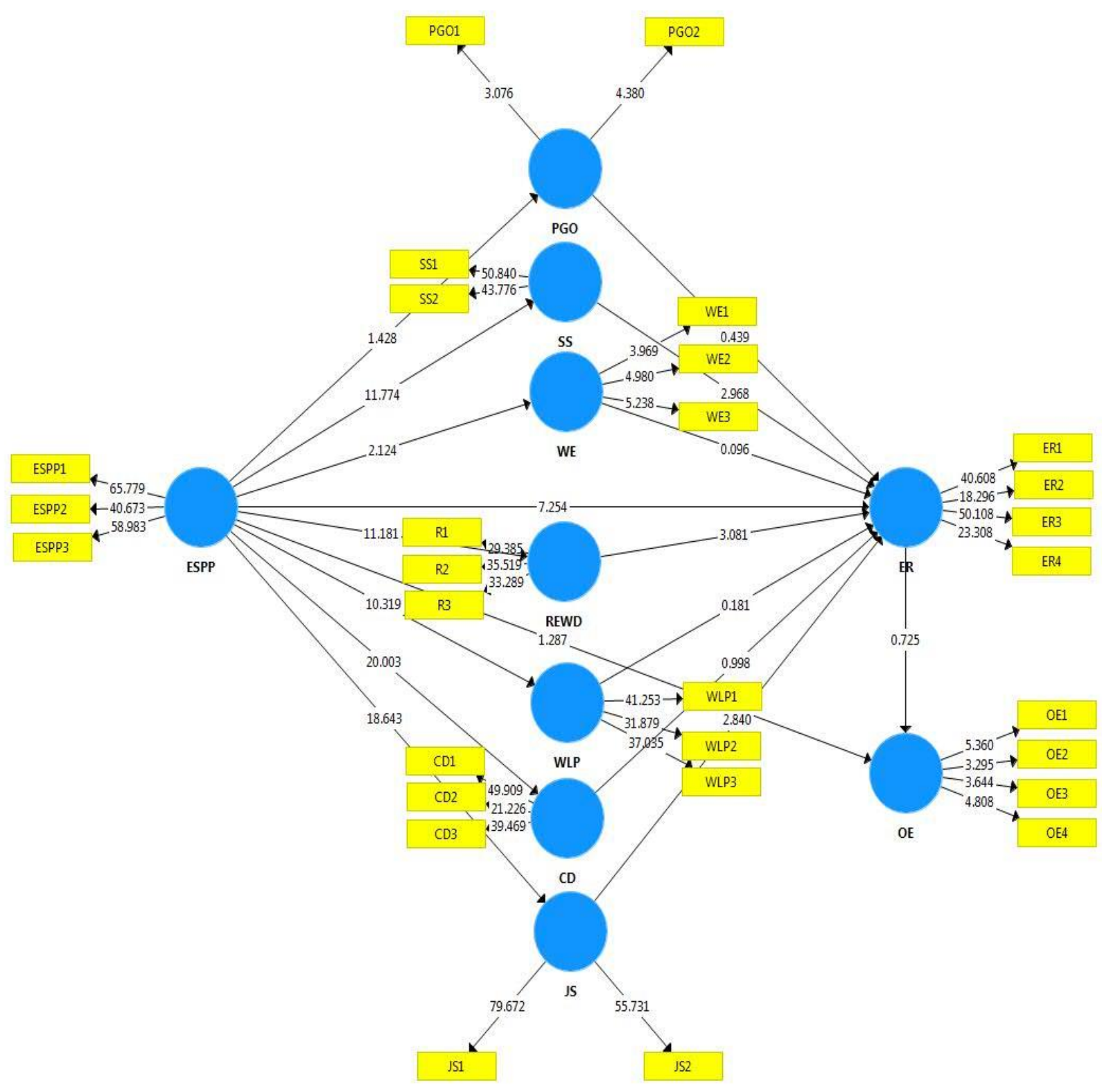

Figure 2.

\subsubsection{Discussions}

The first hypothesis of the present study was there is a positive connection between effective succession planning practices and employee retention. The higher the SP practices in organizations as a result the greater the employee rate of retention. This further implies that if the firm implements an adequate succession planning program it will influence employees' decision to remain with the organization positively because they will believe they have a future with the organization thus a rise in the rate of retention of the organization (Jonathan Tetteh, 2015). Proper effective succession planning practices assist an individual to urge their work performed and also to retain the employees within the organization in a more positive and efficient manner. It is suggested that when effective succession planning practices are 
increasing, there was a possibility for improving employee retention in the private sector organizations in Pakistan. Effective succession planning practices is more important for any organization in order to bring the competent individual ahead to the key roles wherever all the business related decisions are to be taken. If effective succession planning practices carried out effectively as a result, it can enhance the employee rate of retention within the organization. The significant impact of ESPP on ER is also consistent with some previous researches (Eshiteti et al, 2013) and (Poornima W.A.D.N et al, 2018).

The second hypothesis of this study sought to investigate whether there is a significant association between effective succession planning practices \& organizational effectiveness. This outcome isn't inline with the research study of (Jonathan Tetteh, 2015) which found succession planning to have a critical constructive impact on organizational effectiveness.

The third hypothesis of the present study was employee retention is positively connected to organizational effectiveness. The results of this examination have not agreed the hypothesis and indicated that there's no correlation between employee retention and organizational effectiveness.

The H4(c) was a performance goal orientation that mediates the relationship between effective succession planning practices and employee retention. This was also not supported by the results. This is consistent with the findings of (Poornima W.A.D.N et al, 2018) who studied performance goal orientation as a moderator between effective succession planning practices and employee retention and indicated that performance goal orientation was not moderated the relationship between effective succession planning practices and employee retention.

The H5(b) hypothesizing supervisor support is positively related to employee retention was also not supported. This finding is consistent with the findings of (Zafar, Shuana \& Mahmood, Nasir, 2016 and Shoaib et al, 2009). H6(c) was not supported by the results as there is no significant relationship between the working environment and employee retention. This is inconsistent with the findings of (Zafar, Shuana \& Mahmood, Nasir, 2016 and Shoaib et al, 2009) who found that if a firm delivers a proper working environment to its employees, as a result, they are more likely to remain in a firm for a longer period of time.

The results of $\mathrm{H} 7(\mathrm{~b})$ supported the hypothesis that rewards are positively correlated to employee retention. If a firm gives reasonable rewards to its employees on performing well will lead to employee retention for a longer period of duration. This is consistent with the research work of (Zafar, Shuana \& Mahmood, Nasir, 2016 and Shoaib et al, 2009).

This finding of H8(b) is not consistent with the research work of (Zafar, Shuana \& Mahmood, Nasir, 2016 and Shoaib et al, 2009).

Similarly, H9(a) showed that there is a positive relationship between effective succession planning practices and career development. This is consistent with the research work of (Zulqurnain Ali et al, 2019). However, H9(b) was not supported means there is no correlation between career development and employee retention. This is not in line with the research work of (Zafar, Shuana \& Mahmood, Nasir, 2016 and Shoaib et al, 2009). 
The results H9(c) not supported the hypothesis that career development was not playing the role of mediator between effective succession planning practices and employee retention. This is inconsistent with the findings of (Jonathan Tetteh, 2015) who found the link between succession planning and employee retention is significantly strengthened by the introduction of career development program within the firm such that a greater level of career development program maximizes the relationship between succession planning and employee retention, similarly a relationship is weaker when the career development program is low.

The results of H10(a) were consistent with the findings of (Zulqurnain Ali and Aqsa Mehreen, 2018) who found that succession planning develops a feeling of job security while providing professional growth. In other words, it minimizes the risk of job insecurity and trains the employees to appoint them on some key positions in the future.

\section{Conclusion}

The aim of present study was to analyze how ESPP directly or indirectly related to employee retention, and how performance goal orientation, supervisor support, working environment, rewards, work-life policies, career development, and job security mediated this relationship. The findings of this study indicate that there is a positive impact of effective succession planning practices on employee retention. It is implied when an effective succession planning practices is increasing, as a result, there is a possibility of increasing employee retention in the private sector organizations in Pakistan. This is in line with the research work of (Eshiteti et al, 2013) and (Poornima W.A.D.N et al, 2018). Effective succession planning practices is essential for any organization because it enables in bringing the right person forward to the key positions where all the business-related decisions are to be taken. If effective succession planning practices implemented effectively, it can increase employee retention in the organization. (Mhlongo and Harunavamwe, 2017) indicated that succession planning practices are vital for the organization to cater to the problem of potential retirement, death or early exit of workers. The outcome of effective succession planning practices is the availability of competent right individual at the right time and at the right place in order to place him to the key position. Effective succession planning practices can create a high level of employee retention in the organization. Supervisor support rewards, and job security positively mediated the relationship between effective succession planning practices and employee retention. Whereas performance goal orientation, working environment, work-life policies, and career development is not mediated the relationship between effective succession planning practices and employee retention. This study also investigates that effective succession planning practices and employee retention has no impact on organizational effectiveness. The findings of this study responded to the research question that effective succession planning practices are related to the retention of private sector organizations employees. Moreover, effective succession planning practices are likely to be useful in solving the issue of improper selection or appointment of employees in private sector organizations and also contribute to smooth leadership transitions. Concluding remarks are that effective succession planning practices considerably overcome the issue of employee retention among private sector organizations employees while providing supervisor support, rewards, and job security. 


\section{Macrothink \\ International Journal of Human Resource Studies \\ ISSN 2162-3058 \\ 2020, Vol. 10, No. 2}

\section{Limitations and Future Research}

Present research was directed in the private sector organizations just while other studies can be carried out in public sector organizations to look at the connection between effective succession planning practices \& employee retention. Further, this research study can be performed flawlessly with larger sample size in view of the deficiency of time and heaps of burdens, so that this research was restricted to Karachi city.

The individuals who are keen to select this subject for further study should carry out a study of different urban areas of Pakistan. Ultimately this study contributes future researchers to add value to the same chosen topic by distinguishing the area, variables, and reference sector.

\section{References}

Abbasi, S. M., \& Hollman, K. W. (2000). Turnover: The real bottom line. Public personnel management, 29(3), 333-342. https://doi.org/10.1177/009102600002900303

Adebola, S. (2019). Why do organisations run talent programmes? Insights from UK organisations. In Managing Talent (pp. 187-213). Palgrave Macmillan, Cham. https://doi.org/10.1007/978-3-319-95201-7_9

Agarwal, N. C. (1998). Reward systems: Emerging trends and issues. Canadian Psychology/Psychologie canadienne, 39(1-2), 60. https://doi.org/10.1037/h0086795

Ahmad, R. B., Mohamed, A. M. B., \& Manaf, H. B. A. (2017). The relationship between transformational leadership characteristic and succession planning program in the Malaysian public sector. International Journal of Asian Social Science, 7(1), 19-30. https://doi.org/10.18488/journal.1/2017.7.1/1.1.19.30

Ali, Z., \& Mehreen, A. (2019). Understanding succession planning as a combating strategy for turnover intentions. Journal of Advances in Management Research. https://doi.org/10.1108/JAMR-09-2018-0076

Ali, Z., \& Mehreen, A. (2019). Understanding succession planning as a combating strategy for turnover intentions. Journal of Advances in Management Research. https://doi.org/10.1108/JAMR-09-2018-0076

Ali, Z., Mahmood, B., \& Mehreen, A. (2019). Linking succession planning to employee performance: The mediating roles of career development and performance appraisal. Australian Journal of Career Development, 28(2), 112-121. https://doi.org/10.1177/1038416219830419

Ali, Z., Mehmood, B., Ejaz, S., \& Ashraf, S. F. (2014). Impact of succession planning on employees performance: evidence from commercial banks of Pakistan. European Journal of Social Sciences, 44(2), 213-220.

Armstrong, M. (2012). A Handbook of Human Resource Management Practice: (12th Edition), Ashford for Colour Press, UK. 
Bamberger, P., \& Meshoulam, I. (2000). Human resource strategy: Formulation, implementation, and impact. Thousand Oaks, CA: Sage.

Bolander, P., Werr, A., \& Asplund, K. (2017). The practice of talent management: a framework and typology. Personnel Review. https://doi.org/10.1108/PR-02-2016-0037

Borland, J. (1992). Job security in Australia. Journal of Economic Perspectives, 22(1), 115-136.

Brooks, V., \& Henderson, T. (2005). Georgia's flexible succession planning model: growing tomorrow's leaders today. Georgia merit system, 17.

Carmines, E. G., \& Zeller, R. A. (1979). Reliability and validity assessment (Vol. 17). Sage publications. https://doi.org/10.4135/9781412985642

Cheng, G. H. L., \& Chan, D. K. S. (2008). Who suffers more from job insecurity? A $\begin{array}{llll}\text { meta-analytic } \quad \text { review. } & \text { Applied } & \text { 272-303. }\end{array}$ https://doi.org/10.1111/j.1464-0597.2007.00312.x

Chepkwony, N. K. (2012). The Link between Talent Management Practices, Succession Planning and Corporate Strategy among Commercial Banks in Kenya.

Chew, J. C. L. (2004). The influence of human resource management practices on the retention of core employees of Australian organisations: An empirical study (Doctoral dissertation, Murdoch University).

Chin, W. W. (1998). The partial least squares approach to structural equation modeling. Modern methods for business research, 295(2), 295-336.

Chitsaz-Isfahani, A., \& Boustani, H. R. (2014). Effects of talent management on employees retention: The mediate effect of organizational trust. International Journal of Academic Research in Economics and Management Sciences, 3(5), 114. https://doi.org/10.6007/IJAREMS/v3-i5/1196

Colquitt, J. A., \& Simmering, M. J. (1998). Conscientiousness, goal orientation, and motivation to learn during the learning process: A longitudinal study. Journal of applied psychology, 83(4), 654. https://doi.org/10.1037/0021-9010.83.4.654

Cumming, D., Siegel, D. S., \& Wright, M. (2007). Private equity, leveraged buyouts and governance. Journal of Corporate Finance, 13(4), 439-460. https://doi.org/10.1016/j.jcorpfin.2007.04.008

Eisenberger, R., Fasolo, P., \& Davis-LaMastro, V. (1990). Perceived organizational support and employee diligence, commitment, and innovation. Journal of applied psychology, 75(1), 51. https://doi.org/10.1037/0021-9010.75.1.51

Eisenberger, R., Stinglhamber, F., Vandenberghe, C., Sucharski, I. L., \& Rhoades, L. (2002). Perceived supervisor support: contributions to perceived organizational support and employee retention. Journal of applied psychology, 87(3), 565. https://doi.org/10.1037/0021-9010.87.3.565 
Eshiteti, S. N., Okaka, O., Maragia, S. N., Odera, O., \& Akerele, E. K. (2013). Effects of succession planning programs on staff retention. Mediterranean Journal of Social Sciences, 4(6), 157. https://doi.org/10.5901/mjss.2013.v4n6p157

Farashah, A. D., Nasehifar, V., \& Karahrudi, A. S. (2011). Succession planning and its effects on employee career attitudes: Study of Iranian governmental organizations. African journal of business management, 5605-3613. https://doi.org/10.2753/IMO0020-8825400101

Forza, C. (2002). Survey research in operations management: a process-based perspective. International journal of operations \& production management. https://doi.org/10.1108/01443570210414310

Garg, A., \& Weele, E. (2012). Succession Planning and Its Impact on the Performance of Small Micro Medium Enterprises within the Manufacturing Sector in Johannesburg. International Journal of Business and Management. https://doi.org/10.5539/ijbm.v7n9p96

Ghayyur, M., \& Jamal, W. (2012). Work-family conflicts: A case of employees' turnover intention. International Journal of Social Science and Humanity, 2(3), 168. https://doi.org/10.7763/IJSSH.2012.V2.90

Greenhalgh, L., \& Rosenblatt, Z. (1984). Job insecurity: Toward conceptual clarity. Academy of Management review, 9(3), 438-448. https://doi.org/10.5465/amr.1984.4279673

Greenhalgh, L., \& Rosenblatt, Z. (2010). Evolution of research on job insecurity. International Studies of Management \& Organization, 40(1), 6-19. https://doi.org/10.2753/IMO0020-8825400101

Greenhaus, J. H. (1999). The role of goal setting in career management. Management Development Review, 10(4/5), 168-170. https://doi.org/10.1108/EUM0000000004392

Groves, K. S. (2007). Integrating leadership development and succession planning best practices. Journal of management development. https://doi.org/10.1108/02621710710732146

Gulzar, S., \& Durrani, A. (2014). Impact of succession planning on employee engagement in telecommunication sector in Rawalpindi, Pakistan. European Journal of Business and Management, 6(37), 274-281.

Hair, J. F., Black, W. C., Babin, B. J., Anderson, R. E., \& Tatham, R. L. (1998). Multivariate data analysis (Vol. 5, No. 3, pp. 207-219). Upper Saddle River, NJ: Prentice hall.

Hair, J. F., Ringle, C. M., \& Sarstedt, M. (2013). Partial least squares structural equation modeling: Rigorous applications, better results and higher acceptance. Long range planning, 46(1-2), 1-12. https://doi.org/10.1016/j.lrp.2013.01.001

Hall-Ellis, S. D. (2015). Succession planning and staff development-A winning combination. The Bottom Line, 28(3), 95-98. https://doi.org/10.1108/BL-05-2015-0007 


\section{Macrothink}

International Journal of Human Resource Studies

ISSN 2162-3058 2020, Vol. 10, No. 2

Hayes, A. F., \& Preacher, K. J. (2010). Quantifying and testing indirect effects in simple mediation models when the constituent paths are nonlinear. Multivariate Behavioral Research, 45(4), 627-660. https://doi.org/10.1080/00273171.2010.498290

Hee, O. C., Ying, Y. H., Kowang, T. O., Rizal, A. M., \& Ping, L. L. Succession Management Practices And Employee Retention In The Property Industry: Evidence From Malaysia.

Hiltrop, J. M. (1999). The quest for the best: human resource practices to attract and retain talent. European Management Journal, 17(4), 422-430. https://doi.org/10.1016/S0263-2373(99)00022-5

Human Capital Index Report (2005).

Human Resource Development Council, HRDC. (2012).

Hytter, A. (2008). Dark Side Leaders, Work Environment and Employee Health. Retrieved from Växjö University. Studies in Leadership, Entrepreneurship, and Organization Website: hvxu. selehv/forskning/hofreseminarier/2008/080514\% 20DarkSide\% 20Final\% 20version. $p d f$.

Johnson, R. D., Pepper, D., Adkins, J., \& Emejom, A. A. (2018). Succession planning for large and small organizations: A practical review of professional business corporations. In Succession planning (pp. 23-40). Palgrave Macmillan, Cham. https://doi.org/10.1007/978-3-319-72532-1_3

Joseph Jr, F. (2010). Hair Jr, William C. Black, Barry J. Babin, and Rolph E. Anderson, Multivariate data analysis.

Khumalo, F., \& Harris, M. (2008). TOP LEVEL MANAGEMENT SUCCESSION PLAN STRATEGIES. Journal of International Business Strategy, 8(3).

Kraimer, M. L., Seibert, S. E., Wayne, S. J., Liden, R. C., \& Bravo, J. (2011). Antecedents and outcomes of organizational support for development: The critical role of career opportunities. Journal of Applied Psychology, 96(3), 485. https://doi.org/10.1037/a0021452

Locke, E. A., \& Latham, G. P. (1990). A theory of goal setting \& task performance. Prentice-Hall, Inc.

Lucky, E. O. L., Minai, M. S., \& Rahman, H. A. (2013). Impact of job security on the organizational performance in a multiethnic environment. Research journal of business management, 7(1), 64-70. https://doi.org/10.3923/rjbm.2013.64.70

Luna, G. (2012). Planning for an American higher education leadership crisis: The succession issue for administrators. International Leadership Journal.

Maragia, S. (2013). Effects of Succession Planning Programs on Staff Retention. Mediterranean Journal of Social Sciences. 


\section{Macrothink}

International Journal of Human Resource Studies ISSN 2162-3058 2020, Vol. 10, No. 2

Mehrabani, S. E., \& Mohamad, N. A. (2011). Identifying the important factors influencing the implementation of succession planning. International Conference on Information and Finance, 21, 37-41.

Mhlongo, S. B., \& Harunavamwe, M. (2017). Exploring management's perceptions of succession planning and its impact on staff retention at an agricultural company. International Journal of Research, 7.

Nasir, S. Z., \& Mahmood, N. (2016). Determinants of employee retention: An evidence from Pakistan. International Journal of Academic Research in Business and Social Sciences, 6(9), 182-194. https://doi.org/10.6007/IJARBSS/v6-i9/2304

Nyamekye, F. (2012). Impact of motivation on employee retention: a case study of Standard Chartered Bank Ghana Limited (Doctoral dissertation).

Nyanjom, C. R. (2013). Factors influencing employee retention in the state corporations in Kenya. Unpublished thesis Nairobi: University of Nairobi.

Nzuve, S. N. M. (2010). Management of Human Resources-A Kenya Perspective:(2nd and 4th ed.). Kenya: Basic Management Consultants, Nairobi-Kenya.

Odengo, R. A., \& Bett, S. (2016). Influence of Succession Planning Practices on Performance of Kenya Power Limited Company.

Okwakpam, J. A. (2019). EFFECTIVE SUCCESSION PLANNING: A ROADMAP TO EMPLOYEE RETENTION. Kuwait Chapter of the Arabian Journal of Business and Management Review, 8(2), 1-10.

Ontario, (2004). Ministry of Health and Long-Term Care (Report No. Learning series; booklet 4). Long-term care facility worker retention. Ministry of Health and Long-Term Care, recruitment $\&$ retention tactics for the long-term care facility sector, Recruitment $\&$ retention tactics for the long-term care $(127.3 \mathrm{~K})$.

Pennell, K. (2010). The role of flexible job descriptions in succession management. Library management. https://doi.org/10.1108/01435121011046344

Pillay, R. (2009). Work satisfaction of professional nurses in South Africa: a comparative analysis of the public and private sectors. Human resources for Health, 7(1), 15. https://doi.org/10.1186/1478-4491-7-15

Poornima, W. A. D. N., Sutha, J., \& Perera, K. T. (2018). A Study on the Impact of Effective Succession Planning Practices on Employee Retention of Private Business Organizations in Sri Lanka.

Prabhakar, N. P., \& Gowthami, C. (2013). Succession planning-ready, willing but not able: A global perspective.

Prince, B.J. (2005). Career-focused employee transfer processes. Career Development International, 10(4), 293-309. https://doi.org/10.1108/13620430510609136 


\section{Macrothink}

International Journal of Human Resource Studies

ISSN 2162-3058

2020, Vol. 10, No. 2

Qaisar Danish, R., Shahid, F., Bano, S., Fawad Ali, H., \& Afzal Humayon, A. (2019). Supervision Support and Turnover Intension: Impact of Employee's Training in Banking Sector of Pakistan. European Online Journal of Natural and Social Sciences: Proceedings, $8(1(\mathrm{~s})), \mathrm{pp}-121$.

Rothwell, W. J. (2001). Effective Succession Planning: Ensuring Leadership Continuity and Building Talent from Within (2nd ed.). AMACOM, New York, NY.

Rothwell, W. J. (2010). Effective succession planning: Ensuring leadership continuity and building talent from within (4th Ed.). New York, NY: AMACON.

Salaman, G. (2014). Relationship between succession planning practices and employee retention in large media houses in Kenya. Unpublished Dissertation. University Of Nairobi: Kenya.

Schroeder, R. G., Goldstein, S. M., \& Rungtusanatham, M. J. (2013). Operations Management in the Supply Chain: Decision and Cases. Sixth Edition. United States of America: McGraw-Hill.

Shoaib, M., Noor, A., Tirmizi, S. R., \& Bashir, S. (2009). Determinants of employee retention in telecom sector of Pakistan. Proceedings of the 2nd CBRC, Lahore, Pakistan, 14, $1-18$.

Shrout, P. E., \& Bolger, N. (2002). Mediation in experimental and nonexperimental studies: new procedures and recommendations. Psychological methods, 7(4), 422. https://doi.org/10.1037/1082-989X.7.4.422

SIA. (2018). "Employee Retention Remains Top Workforce Challenge, SHRM Survey Finds". Www2.Staffingindustry.Com.

Silbert, L. (2005). The effect of tangible rewards on perceived organizational support (Master's thesis, University of Waterloo).

Stadler, K. (2011). Talent reviews: the key to effective succession management. Business Strategy Series. https://doi.org/10.1108/17515631111166906

Staufenbiel, T., \& König, C. J. (2010). A model for the effects of job insecurity on performance, turnover intention, and absenteeism. Journal of Occupational and Organizational Psychology, 83(1), 101-117. https://doi.org/10.1348/096317908X401912

Tetteh, J. O. N. A. T. H. A. N. (2015). Succession Planning, Employee Retention and Organisational Effectiveness among Some Selected Organisations in Ghana (Doctoral dissertation, University of Ghana).

van der Hejden, S. (86). R. \& van Veldhoven, JPM (2008). Ageing and careers: European research on long-tem career development and early retirement. Career Development International, 13(2), 85-94. https://doi.org/10.1108/13620430810860512 


\section{Macrothink}

International Journal of Human Resource Studies

ISSN 2162-3058 2020, Vol. 10, No. 2

Van der Sluis, L. E., \& Poell, R. F. (2003). The impact on career development of learning opportunities and learning behavior at work. Human Resource Development Quarterly, 14(2), 159-179. https://doi.org/10.1002/hrdq.1058

VandeWalle, D., Brown, S. P., Cron, W. L., \& Slocum Jr, J. W. (1999). The influence of goal orientation and self-regulation tactics on sales performance: A longitudinal field test. Journal of Applied Psychology, 84(2), 249. https://doi.org/10.1037/0021-9010.84.2.249

\section{Copyright Disclaimer}

Copyright for this article is retained by the author(s), with first publication rights granted to the journal.

This is an open-access article distributed under the terms and conditions of the Creative Commons Attribution license (http://creativecommons.org/licenses/by/4.0/). 